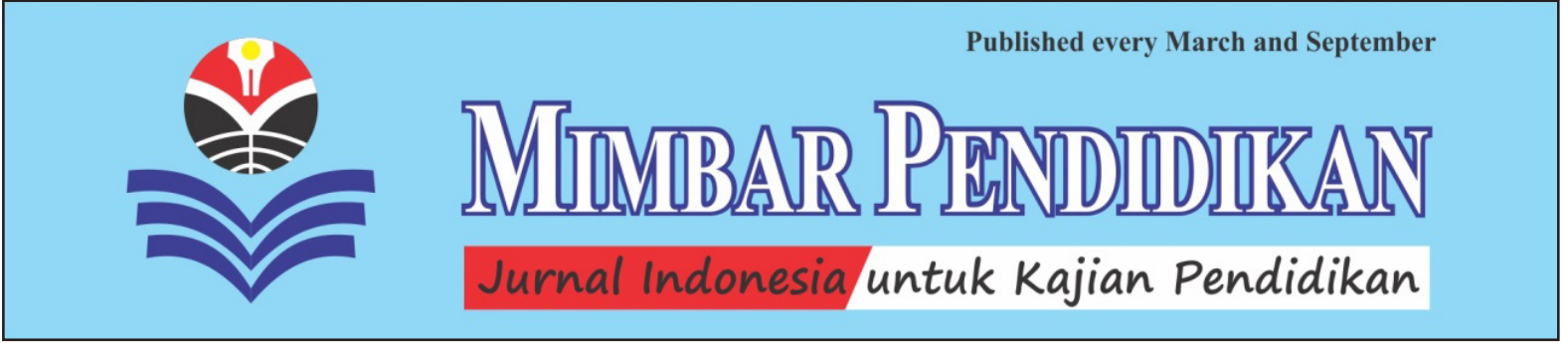

\title{
Assessing and Enhancing Emotional Intelligence among Nigerian Librarians
}

\begin{abstract}
The democratization process in Nigeria has been dismally slow owing to issue of leadership in Nigeria, especially among the librarians. Researchers have attributed this prevalent tendency of the Nigerian librarians not being able to manage library failures and successes to inadequacies of emotional intelligence requisite for career progression and professional self-actualization. There is dearth of research in the area of assessing and enhancing emotional intelligence among Nigerian librarians. Attempts made to uncover related studies in this area have proved abortive. It is anticipated that the position of this paper will provide baseline information for research as to how emotional intelligence affects leadership styles in the library organisation. By using the qualitative approaches and literature review, this study tries to elaborate key concepts of leadership and its relationship with the Nigerian librarians, such as: Concept of Emotional Intelligence; Emotional Intelligence and Leadership; Leadership and Leadership Style; the Transformational-Transactional Leadership Style Theory by J.M. Burns was Used to Explain the Concept of Leadership Style; and Relevance of J.M. Burns Theory to this Study.
\end{abstract}

KEY WORD: Assessing; Enhancing; Emotional Intelligence; Nigerian Librarians.

ABSTRAKSI: "Menilai dan Meningkatkan Kecerdasan Emosional diantara Pustakawan Nigeria". Proses demokratisasi di Nigeria berjalan sangat lambat karena isu kepemimpinan di Nigeria, khususnya di kalangan pustakawan. Para peneliti telah mengaitkan kecenderungan umum dari pustakawan Nigeria yang tidak mampu mengelola kegagalan dan keberhasilan perpustakaan ini dengan ketidakcukupan kecerdasan emosional yang diperlukan untuk kemajuan karier dan aktualisasi diri profesional. Ada kelangkaan penelitian di bidang menilai dan meningkatkan kecerdasan emosional diantara pustakawan Nigeria. Upaya yang dilakukan untuk mengungkap studi terkait di bidang ini terbukti gagal. Posisi makalah ini diantisipasi akan memberikan informasi dasar untuk penelitian tentang bagaimana kecerdasan emosional mempengaruhi gaya kepemimpinan dalam organisasi perpustakaan. Dengan menggunakan pendekatan kualitatif dan kajian pustaka, penelitian ini mencoba menguraikan konsep-konsep kunci kepemimpinan dan hubungannya dengan pustakawan Nigeria, seperti: Konsep Kecerdasan Emosional; Kecerdasan Emosional dan Kepemimpinan; Kepemimpinan dan Gaya Kepemimpinan; Teori Gaya Kepemimpinan Transformasional-Transaksional oleh J.M. Burns Digunakan untuk Menjelaskan Konsep Gaya Kepemimpinan; serta Relevansi Teori J.M. Burns dengan Studi ini.

KATA KUNCI: Menilai; Meningkatkan; Kecerdasan Emosional; Pustakawan Nigeria.

About the Authors: Prof. Adetoun Omolola Idowu, Ph.D. is a Lecturer at the Department of Library Science, Faculty of Communication and Information Sciences, UNILORIN (University of Ilorin) in Ilorin, Nigeria. Lateef Omotosho Adegboyega, Ph.D. is a Lecturer at the Department of Counsellor Education, Faculty of Education, UNILORIN in Ilorin, Nigeria. For academic interests, the Authors are able to be contacted via e-mail address at: adetouni@yahoo.com and adegboyega.lo@unilorin.edu.ng

Suggested Citation: Idowu, Adetoun Omolola \& Lateef Omotosho Adegboyega. (2020). "Assessing and Enhancing Emotional Intelligence among Nigerian Librarians" in MIMBAR PENDIDIKAN: Jurnal Indonesia untuk Kajian Pendidikan, Volume 5(2), September, pp.101-116. Bandung, Indonesia: UPI [Indonesia University of Education] Press, ISSN 2527-3868 (print) and 2503-457X (online).

Article Timeline: Accepted (July 27, 2020); Revised (Agustus 30, 2020); and Published (September 30, 2020). 


\section{INTRODUCTION}

The success of any organization depends on the leader and the leadership style use in driving the organizational processes. This makes leadership studies or researches a recurrent exercise. The success or failure of any organisation is attributable to its leadership, who inspires and directs the staff to achieve defined goals. This implies that in order to maximize the efforts and productivity of a workforce, a formal effective leadership must be in place. This leadership must be task-oriented with the ability to influence the workers towards achievement of personal and organisational goals (Kolzow, 2014; Appelbaum et al., 2015; and Cannella \& Monroe, 2017).

Effective leaders would combine practical strategies and interpersonal procedures to create commitment and loyalty, which would generate outcomes that would give organizations a competitive edge (Cooper, 2017; Li et al., 2019; and Petrick et al., 2019). Leadership revolves around human relationships. This relationship is between those in positions of authority and those who are expected to obey and follow their directives and guidelines. Success in leading, then, becomes dependent upon the capacity of the leader to build and nurture those relationships that cause people to do extraordinary things (Kouzes \& Posner, 2012; Kolzow, 2014; and Bamidele \& Awoyemi, 2017).

Libraries have the hierarchical structure of management. Policies are formulated at the apex and passed down the chain of authority for implementation. Leaders in a library are head of the libraries, sections, and units of the institution. They manage the work performance of their sub-ordinates through duty scheduling, coordination of routine activities, supervising, delegating, evaluating, and disciplining as the need arises (Certo, 2012; Osuigwe et al., 2013; and Bamidele \& Awoyemi, 2017).

ICT (Information and Communication
Technology) has brought challenges to leadership in libraries by creating a dynamic environment, which is constantly changing through technological innovations that require human adaptation. To meet these challenges and survive in the changing world, library leaders need clusters of competencies that will empower them to remain in control, innovative, and achieve defined objectives (Reilly, 1998; Mulcahy, 1999; and Faulk, Lambert \& Rolston, 2005).

Empirical research highlight clusters of competencies, which enable leaders to excel in organisations. These are intellectual or cognitive abilities, self-management or intrapersonal abilities, and relationship management or interpersonal abilities. The latter two groups of competencies are considered part of the emotional intelligence proficiencies (Boyatzis et al., 1999; Kővári, 2016; and Truninger et al., 2018).

The focus of this paper, therefore, is to assess and enhance emotional intelligence among Nigerian librarians, which becomes imperative if the country is to develop maximally in all facets of national development bearing in mind its huge human and material resources. This is essential because the population and spread of Nigeria in the African continent demands that everything must be done to preserve her corporate existence as a guarantee for the security of her neighbours and dependant nations. Thus, the introduction or research into any mechanism likely to enhance the leadership performance of Nigeria librarians is worthwhile ( $c f$ Fry, Ketteridge \& Marshall eds., 2009; Stephen, 2016; and Alabi, 2018).

By using the qualitative approaches and literature review (Aitken \& Herman, 2009; Gentles et al., 2016; and Snyder, 2019), this study tries to elaborate key concepts of leadership and its relationsship with the Nigerian librarians, such as: (1) Concept of Emotional Intelligence; (2) Emotional Intelligence and Leadership; (3) Leadership and Leadership Style; (4) the 
Transformational-Transactional Leadership Style Theory by J.M. Burns was Used to Explain the Concept of Leadership Style; and (5) Relevance of J.M. Burns Theory to this Study.

\section{RESULTS AND DISCUSSION Concept of Emotional Intelligence.}

There are many scholars studies and discussed on EI (Emotional Intelligence).

One of them is J. Manktelow \& A. Carlson (2014), who tried to describe the EI, as following here:

\begin{abstract}
Emotional intelligence is the ability to recognize your emotions, understand what you are being told, and realize how your emotions affect people around you. Emotional intelligence also involves your perception of others; when you understand how they feel, this allows you to manage relationships more effectively (Manktelow \& Carlson, 2014).
\end{abstract}

People with high EI (Emotional Intelligence) are usually successful in most things they do. This is because they are the ones that other people want on their team. When people with high EI send an email, it gets answered. When they need help, they get it; because they make others feel good, they go through life much more easily than people who are easily angered or upset (Goleman, 1995; Manktelow \& Carlson, 2014; and Singhal, Garg \& Saxena, 2014).

EI is also the ability of a person to use emotions as a guiding tool for interpersonal effectiveness in his or her social environment. It is the ability to sense, understand, and effectively apply the power and acumen of emotions as a source of human energy, information, trust, creativity, and influence (Karim, 2011; Singhal, Garg \& Saxena, 2014; and Adegboyega, 2016).

There are four branches of EI. In this context, J.D. Mayer \& P. Salovey (1997), and other scholars, proposed a model that identified four different factors of EI: the perception of emotion; the ability to reason using emotions; the ability to understand emotion; and the ability to manage emotions (Mayer \& Salovey, 1997; Adegboyega, 2016; and Fiori \& Vesely-Maillefer, 2018).

Firstly, Perceiving Emotions: the first step in understanding emotions is to accurately perceive them. In many cases, this might involve understanding nonverbal signals, such as body language and facial expressions (Mayer \& Salovey, 1997; Norris, 2014; and Sauter, 2017).

Secondly, Reasoning with Emotions: the next step involves using emotions to promote thinking and cognitive activity. Emotions help prioritize what we pay attention and react to; we respond emotionally to things that garner our attention (Mayer \& Salovey, 1997; Pasha, 2016; and Cherry, 2018).

Thirdly, Understanding Emotions: the emotions that we perceive can carry a wide variety of meanings. If someone is expressing angry emotions, the observer must interpret the cause of their anger and what it might mean. For example, if a boss is acting angrily, it might mean that he is dissatisfied with his worker's work; or it could be because he got a speeding ticket on his way to work that morning or that he's been fighting with his wife (Mayer \& Salovey, 1997; Grandey, 2000; and O'Brien \& Linehan, 2014).

Fourthly, Managing Emotions: the ability to manage emotions effectively is a key part of emotional intelligence. Regulating emotions, responding appropriately, and responding to the emotions of others are all important aspects of emotional management (Mayer \& Salovey, 1997; Kerr et al., 2006; and Serrat, 2017).

Emotional Intelligence and Leadership. Emotional intelligence moods and emotions in the workplace influence several critical job variables, such as work performance, creativity, and commitment. The ability to manage these moods and emotions, so as to achieve the desired performance level, is 
known as EI (Emotional Intelligence). So, EI has become increasingly popular as a measure for identifying potentially effective leaders, and as a tool for developing effective leadership skills in Nigeria library and information science (Kerr et al., 2006; Langley, 2010; and Srivastava, 2013).

One of the most applied constructs, which EI has been associated with is that of leadership. The leadership literature has produced countless theories outlining which characteristics compose the most effective leader, however, current academic research in the area describes two distinct types of leaders: transformational and transactional (Kerr et al., 2006; Batool, 2013; and Mandell \& Pherwani, 2013).

Transformational leader stimulates interest among colleagues, inspires a different outlook on the work, generates an awareness of the goals of the organization, develops others to higher level of ability, and motivates others to consider the interests of the group over their own interests. Along these lines, transformational leadership is said to comprise the following four dimensions: idealized influence, inspirational motivation, intellectual stimulation, and individual consideration (Bass \& Avolio, 2013; Batool, 2013; and Dev, 2015).

Alternatively, the transactional leader is one who rewards (or disciplines) staff on the basis of their performance. They emphasize work standards, task completion, and employee compliance, while relying heavily on organizational rewards and punishments to influence employee performance (Bass \& Avolio, 2013; Batool, 2013; and Jenner, 2019).

P. Salovey \& J.D. Mayer (1990), and other scholars, introduced the concept of "Emotional Intelligence" in their works, which combines cognition, emotion, and intelligence. EI (Emotional Intelligence) represents a set of dispositional attributes for monitoring one's own and others' feelings, beliefs, and internal states in order to provide useful information to guide one's and others' thinking and action (cf Salovey \& Mayer, 1990; Carson, Carson \& Birkenmeier, 2010; Adegboyega, 2016; and Jenner, 2019).

EI has become a popular topic in the business press in recent years. According to Bano Fakhra Batool (2013), and other scholars, EI has become increasingly popular as a measure for identifying potentially effective leaders, and as a tool for developing effective leadership skills. There is little empirical research that substantiates the efficacy of EI in these areas (Kerr et al., 2006; Batool, 2013; and Adegboyega, 2016).

EI embraces and draws from numerous other branches of behavioural emotional and communication theories, such as NLP (Neuro-Linguistic Programme), Transactional Analysis, and Empathy. The assumption of these theories is that individuals with EI are assisted to become productive and successful at what they do, and help others to become more productive and successful equally (Batool, 2013; Ugoani, 2015; and Jenner, 2019).

It has been observed that the presence of EI in an individual, for example a Nigerian librarian, enables such a person to benefit from elements inherent in EI known for their potency in reducing stress for individuals and organizations by decreasing conflict and improving relationships (Sani et al., 2013; Alreshidi, 2018; and Hendrix, 2018).

The human society is a complex entity that requires constant adaptation and adjustment in order to ensure continuous harmony among its diverse population. This is in line with the notion of C. Darwin (1872), and other scholars, when they propagated the idea of emotional expression for survival and successful adaptation (Darwin, 1872; Bergman, 2018; and Ludwig \& Welch, 2019).

Similar to the submission of B. Mandell 
\& S. Pherwani (2013), and other scholars, there are two classes of leaders identified by current literature on leadership, i.e. the transformation and the transactional leaders with their characteristic personality profile malleable for efficient manpower mobilization based on their possession of four dimensions: idealized influence, inspirational motivation, intellectual stimulation, and individual consideration (Brown \& Reilly, 2008; Bass \& Avolio, 2013; and Mandell \& Pherwani, 2013).

Research studies have shown that EI is a veritable tool for purposeful leadership and result-oriented governance. EI has equally been identified as means of marking out potentially efficient leaders, who possess requisite characteristics for mass mobilization as a pre-condition for national development (Allen, Shankman \& Miguel, 2012; Batool, 2013; and Bausseron, 2018).

Similarly, B. Mandell \& S. Pherwani (2013), and other scholars, noted that EI is required for the production of the two main classes of leaders-transformational and transactional leaders with attendant personality profile for required manpower mobilization and peaceful co-existence (Brown \& Reilly, 2008; Bass \& Avolio, 2013; and Mandell \& Pherwani, 2013).

Furthermore, R. Bar-On (2019), and other scholars, noted that emotional expression is a requisite condition for manifestation of adaptive leadership that is capable of adjusting to varying environmental demands and requirements in line diverse population exigencies (Yukl \& Mahsud, 2010; Walters, 2018; and Bar-On, 2019).

\section{Leadership and Leadership Style.}

Organizations, such as library, are established to accomplish some laid out objectives. To attain this, the human factor is of paramount standing. In place of the human factor is the leader. In this context, G. Kraines (2011), and other scholars, emphasized that leadership has become a reoccurring word that has been used in most disciplines (Shrestha, 2008; Kraines, 2011; and Omeluzor, 2018).

However, different scholars have given different meaning to this concept. R.E. Riggio, I. Chaleff \& J. Lipman-Blumen eds. (2008), and other scholars, for example, described leadership as a learning process that is centrally associated with what needs to be said about what others understand and follow. Therefore, this is mostly concerned with leader-follower relationship. They, further, expressed that it is an ongoing process whereby the leader and follower may change their roles (Riggio, Chaleff \& Lipman-Blumen eds., 2008; Malakyan, 2015; and Read III, 2018).

It is seen as the dynamic processes at work in an assembly, whereby employees are freely committed to organizational goals and objectives in terms of achieving them. Leadership is one major concept studied in the social sciences the most. The analysis accorded to leadership is not so groundbreaking, considering the fact that it is a global phenomenon objectively evolving in humanity and in animal classes (Cole, 2012; Kolzow, 2014; and Bass, 2018).

Shying away from the well-known leadership styles, such as autocratic, democratic and laissez-faire leadership styles, in recent times, two major types of leadership styles that have attracted the attention of scholars are: transformational and transactional leadership styles.

Researchers in their various studies believe that transformational and transactional leadership styles encompass every other kind of leadership styles (Foster, 2002; Woods, 2010; and Amanchukwu, Stanley \& Ololube, 2015).

Studies in the context of these contemporary leadership styles have actually been the favourites of many researchers. Leadership in establishments is characteristically observed as the mixture of staff and board leadership to attain their tasks. In this context, R.E. Drucker 
(2010), and other scholars, stated that for organizations to be operative, employee leaders must labour cooperatively with their boards, but it is the policy making officers who are the stronger players (Leithwood et al., 2004; Drucker, 2010; and Baker, Campbell \& Ostrof, 2015).

According to K.B. Lowe, K.G. Kroeck $\&$ N. Sivasubramaniam (2016), and other scholars, transformational leadership is an active leadership style, which enhances organizational performance. Transformational leadership laid emphases on moving the organization's approaches and culture to fit better with the adjoining environment. Transformational leaders are modification mediators who strengthen employees and direct them to a new set of business values (Kotter, 2011; Kolzow, 2014; Singh, 2014; and Lowe, Kroeck \& Sivasubramaniam, 2016).

Transformational leadership has four dimensions: (1) idealized influence that is attaining follower respect and belief; (2) inspirational motivation, which means providing significance and task in follower's work; (3) intellectual stimulation, which entails imploring new philosophies and cheering imaginative problem solving; and (4) individualized consideration that is giving consent to followers' desires (Mullin \& Keedy, 1998; Bass \& Avolio, 2013; and Milius, 2019).

In their study on ethical preferences of transformational leaders, Priyanka Banerji \& Venkat R. Krishnan (2000), and other scholars, recounted that transformational leadership includes inspiring, mustering, uplifting, and raising the moral objectives of the leader and of the led (Banerji \& Krishnan, 2000; Lee, 2014; and Taylor, 2015). Going by the meta-analysis findings of studies in transformational leadership literature, K.B. Lowe, K.G. Kroeck \& N. Sivasubramaniam (2016), and other scholars, reported that individuals who displayed transformational leadership were seen to be real leaders with better work results than individuals, who showed only transactional leadership traits. They decided that there was a robust connection between all the constituents of transformational leadership and subordinate satisfaction with supervision (Kolzow, 2014; Lowe, Kroeck \& Sivasubramaniam, 2016; and Li et al., 2019).

In a study by G. Jandaghi, H.Z. Martin \& A. Farjami (2019), and other scholars, it was revealed that several components of transformational leadership style were more significant in successful organizations over unsuccessful organizations. They revealed that idealized influence had a strong domination in successful organization than unsuccessful organization. Even, within categorized successful organization, idealized influence and inspirational motivation had greater mean scores than other components of transformational leadership (Hughes, 2014; Jandaghi, Martin \& Farjami, 2019; and Li et al., 2019).

In a study by O.A. Ipuele \& A.F. Aondoaseer (2013), and other scholars, on leadership styles as recipes for transformation, it was revealed that employees were willing to work better with a transformational leader than a transactional leader. They found succour in transformational leaders, in the sense that the leader of the organization always motivate them when they do well in their work and is always willing to carry them along in decision making process of the organization. The employees were also of the opinion that being that they had a transformational leader as their boss; they have never nursed any form of fear or apprehensiveness when carrying out various duties (Ipuele \& Aondoaseer, 2013; Dias \& Borges, 2017; and Li et al., 2019).

Also, in a study by A.M. Karavelioglu (2014), and other scholars, on analysis of leadership styles in banking sector in North Cyprus, it was reported that employees in 
the banking sector in this country had a sense of belonging with the managers of the banks, because they were motivating, encouraging loving, and friendly. The study also revealed that employees saw their managers and departmental supervisors as people they could always confide in and share issues centred on their job. Most times, the employees displayed high sense of confidence when carrying out their duties (cf Karavelioglu, 2014; Wijesundera, 2018; and Evangelides \& Karfakis, 2019).

A study by Z.D. Gellis (2011), and other scholars, which comprised of 187 committed social workers from 26 hospitals in a large urban setting discovered that transformational leadership did have substantial and considerable add-on belongings to transactional leadership in the forecast of apparent success and approval with the leader in a social work sample. The study also revealed that social workers relied heavily on their immediate bosses in order for them to convey out their jobs meritoriously and professional ally simply because they were transformational in nature (Gellis, 2011; Desrosiers, 2015; and Higgins, 2015).

\section{The Transformational-Transactional} Leadership Style Theory by J.M. Burns was Used to Explain the Concept of Leadership

Style. Transformational leadership is defined as a leadership style that brings about change in individuals and social organizations. In its model form, it generates cherished and optimistic modification in the followers with the aim of evolving followers into leaders. Endorsed in its genuine form, transformational leadership improves the inspiration, confidence, and performance followers through a variability of mechanisms. These include linking the follower's sense of individuality and self to the mission and the cooperative uniqueness of the firm; being a character model for followers that stimulates them; challenging followers to take superior tenure for their work; and understanding the strengths and weaknesses of followers, so the leaders can align followers with tasks that enhance their performance (Burns, 1978 and 2003; Kolzow, 2014; and Gomes, 2018).

According to J.M. Burns (1978 and 2003), and other scholars, the transformational method produces momentous change in the lives of people and organizations. It reformats observations and standards, and changes expectations and ambitions of employees. Unlike in the transactional approach, it is not based on a "give and take" relationship, but on the leader's personality, traits and ability to make a change through example, expression of an energizing vision and stimulating goals (Burns, 1978 and 2003; Ayalew, 2012; and Lubke, 2013).

Transforming leaders are idealized, in the sense that they are a moral paradigm of working near the benefit of the team, organization, and community. Again, J.M. Burns (1978 and 2003), and other scholars, theorized that transformational and transactional leadership were jointly exclusive styles. Transactional leaders typically do not strive for cultural modification in the organization, but they labour in the standing culture; while transformational leaders can try to change organizational culture (Burns, 1978 and 2003; Bass \& Avolio, 2014; and Bass, 2018).

Transformational leadership, according to the theory, has the following indicators:

Firstly, Idealized Influence. This distinctive leadership style describes the extent to which leaders are proficient of being role models to their followers and show concrete moral and ethical principles. Idealized influence is defined in two types: quantified, i.e. what traits are assigned to a leader; and communicative, i.e. what one does (Burns, 1978 and 2003; Kolzow, 2014; and Li et al., 2019).

Secondly, Inspirational Motivation. This characteristic replicates the extent to which 
a leader is also skilled of being a cheer leader, so to speak, on behalf of his or her followers. These leaders validate enthusiasm and optimism, and accentuate commitment to a shared goal (Burns, 1978 and 2003; Dawkins, 2011; and Li et al., 2019).

Thirdly, Intellectual Stimulation. Transformational leadership inculcates originality, as well-followers are stimulated to approach problems in new ways. It enables intelligently inspiring leaders to relate statements, such as: "I re-examine critical assumptions to question whether they are appropriate" and "I suggest new ways looking at how to complete assignments" (Burns, 1978 and 2003; Bass \& Avolio, 2014; and Li et al., 2019).

Fourthly, Individualized Consideration. Transformational leaders invest a lot in the expansion of their followers-they assist also as mentors and instructors, and take into justification individual wants and requirements within a group. Twoway communication is predominantly acknowledged. Transactional leadership, also acknowledge as managerial leadership, emphasizes on the role of supervision, organization, and group performance; transactional leadership is a style of leadership in which the leader encourages compliance of his/her followers through both recompenses and penalties (Burns, 1978 and 2003; Lea, 2019; and Li et al., 2019).

Unlike transformational leadership, leaders using the transactional approach are not looking to change the future; they are looking to simply keep things the same. These leaders pay consideration to followers' work in order to find errors and abnormalities. This type of leadership is actual in calamity, reserve in unpleasant situations, and when projects need to be approved in a specific fashion (Odumeru \& Ogbonna, 2013; Ramesh \& Hegde, 2017; and Lea, 2019).

Transactional leaders are concerned with developments rather than forward-thinking ideas. These type of leaders center on contingent reward. Contingent rewards, such as praise, are assumed when the set goals are achieved on-time, ahead of time, or to keep subordinates working at a good pace at different times (Yukl \& Mahsud, 2010; Xenikou, 2017; and Lea, 2019).

Contingent punishments, such as suspension, are given when performance value or amount decreases below production standards or objectives and responsibilities are not met at all. Frequently, contingent penalties are handed down on a management-by-exception basis. Within management-by-exception, there are active and passive routes. Active management-byexception means that the leader continually looks at each subordinate's performance and makes changes to the subordinate's work to make corrections throughout the process. Passive management-by-exception leaders wait for issues to come up before fixing the problems. With transactional leadership being functional to lower-level needs and being more managerial in style, it is a foundation for transformational leadership which applies to higher-level needs (Thomson, 1998; Kolzow, 2014; and Amanchukwu, Stanley \& Ololube, 2015).

\section{Relevance of J.M. Burns Theory to this}

Study. Transformational-transactional theory was used to buttress the variable-leadership style in this paper. This approach provides justification for the need for managers to acquire good leadership skill that will be most appealing to their employees so as to increase the performance level of their organization. If an organization is headed by a transformational leader, the leader is careful enough to exhibit characters that are embraceable by his/her followers since the whole idea behind his/her style of leadership is that followers should be able to emulate their leader who serves as an influence over them (Burns, 1978 and 2003; Abbas \& Asghar, 2010; and Mansaray, 2019). 
In the case of library, it is expected that if heads (librarians) of this type of organization are worth emulating in character, employees will be able to contribute meaningfully well to the development of their organization. On the part of transactional leadership style theory, which is premises on get try the job done and ensure the participants are rewarded, heads of organizations must realized that first and foremost that without the employees the organization cannot move on (Keskes, 2014; Kolzow, 2014; and Li et al., 2019).

Therefore, the responsibility of the head of the organization to introduce various reward system in their libraries so as to enable employees always put in their best to their work as this action would singularly position their organisations to achieve maximum performance (Roberts, 2005; Bushiri, 2014; and Nwokocha, 2016).

\section{CONCLUSION}

Leadership style in an organization is one of the factors that play significant role in enhancing or retarding the interest and commitment of the individuals in the organization. It is the manner and approach of providing direction, motivating people, and achieving objectives. The leadership styles adopted by a leader have a great influence on employee motivation, staff empowerment, and the success of any change introduction.

Leaders at all levels are, therefore, advised to reconcile their leadership styles with both the prevailing circumstances and the requirements of their assignments if they must achieve positive results or achieve the goals/objectives of their organizations. ${ }^{1}$

\footnotetext{
${ }^{1}$ Statement: We, hereby, declare that this scientific article, that we wrote, has never been submitted for publication in any other journals. In this article, there is no work or opinions that have been written or published in another person, except in writing clearly listed as the sources listed in the Bibliography or References. So, this article is really not product of plagiarism.
}

\section{References}

Abbas, Wasim \& Imran Asghar. (2010). "The Role of Leadership in Organizational Change: Relating the Successful Organizational Change to Visionary and Innovative Leadership". Unpublished Master's Thesis. Sweden: Faculty of Engineering and Sustainable Development, University of Gavle. Available online also at: https://www.diva-portal.org/smash/get/ diva2:326289/FULLTEXT01.pdf\&gt [accessed in Ilorin, Nigeria: September 9, 2019].

Adegboyega, L.O. (2016). "Relationship between Emotional Intelligence and Attitude towards Examination of Undergraduates at University of Ilorin". Unpublished Academic Paper presented at the Department of Counsellor Education UNILORIN (University of Ilorin) in Ilorin, Nigeria.

Aitken, Stuart C. \& Thomas Herman. (2009). "Literature Review on Qualitative Methods and Standards for Engaging and Studying Independent Children in the Developing World". Innocenti Working Papers for UNICEF [United Nations Children's Fund].

Alabi, G.A. (2018). "Telecommunications in Nigeria". Available online at: http://www.africa.upenn.edu/ ECA/aisi inftl.html [accessed in Ilorin, Nigeria: August 10, 2019].

Allen, Scott J., Marcy Levy Shankman \& Rosanna F. Miguel. (2012). "Emotionally Intelligent Leadership: An Integrative, Process-Oriented Theory of Student Leadership" in Journal of Leadership Education, Vol.11, Iss.1

[Winter]. Available online also at: https:// journalofleadershiped.org/wp-content/ uploads/2019/02/11 1 Allen-Shankman-andMiguel.pdf [accessed in Ilorin, Nigeria: August 24, 2019].

Alreshidi, Maha Sanat. (2018). “The Impact of a Training Intervention on Emotional Intelligence, Leadership Styles, Self-Efficacy and Perception of Sense of Power in a University Nursing Faculty in Saudi Arabia". Unpublished Ph.D. Thesis. England: School of Health and Society, University of Salford. Available online also at: https://usir.salford.ac.uk/id/eprint/50716/1/ Corrected\%20final\%20PhD\%20thesis\%2026-32019\%20(TL)-.pdf [accessed in Ilorin, Nigeria: August 24, 2019].

Amanchukwu, R.N., G.J. Stanley \& N.P. Ololube. (2015). “A Review of Leadership Theories, Principles, and Styles and Their Relevance to Educational Management" in Management, Vol.5, No.1, pp.6-14. doi:10.5923/j.mm.20150501.02. 
Appelbaum, Steven H. et al. (2015). “Organizational Outcomes of Leadership Style and Resistance to Change (Part One)" in Industrial and Commercial Training, Vol.47, Iss.2, pp.73-80. Available online also at: http://dx.doi.org/10.1108/ICT-07-20130044 [accessed in Ilorin, Nigeria: August 10, 2019].

Ayalew, Anteneh Tsegaye. (2012). "An Integrative Approach to Intercultural Communication in Context: Emprical Evidences from Higher Education". Unpublished Ph.D. Dissertation. Giessen, Germany: Justus Liebieg University. Available online also at: http://geb.unigiessen.de/geb/volltexte/2014/10626/pdf/ AyalewAnteneh 2012 06 26.pdf [accessed in Ilorin, Nigeria: September 9, 2019].

Baker, Troy, Stephen Campbell \& Dave Ostrof. (2015). "Independent School Leadership: Heads, Boards and Strategic Thinking”. Available online at: https://www.nais.org/articles/documents/ member/school-leadership-heads-boardsstrategic-thinking.pdf [accessed in Ilorin, Nigeria: August 31, 2019].

Bamidele, Olawale \& Olubunmi O. Awoyemi. (2017). "Delegation of Responsibilities: A Leadership Tool for Subordinates' Competence Development in Selected Academic Libraries in Nigeria" in International Journal of Library Science, Vol.6, No.4, pp.69-76. doi:10.5923/j. library.20170604.01.

Banerji, Priyanka \& Venkat R. Krishnan. (2000). "Ethical Preferences of Transformational Leaders: An Empirical Investigation" in Leadership \& Organization Development Journal, Volume 21(8), pp.405-413. Available online also at: http:// www.rkvenkat.org/priyanka.pdf [accessed in Ilorin, Nigeria: August 31, 2019].

Bar-On, R. (2019). Bar-On Emotional Quotient Inventory: A Measure of Emotional intelligence Technical Manual. Toronto, Canada: Multi-Health Systems.

Bass, B.M. (2018). The Bass Handbook of Leadership: Theory, Research, and Managerial Applications. New York: Free Press, $4^{\text {th }}$ edition.

Bass, B. \& B. Avolio. (2013). "Transformational Leadership and Organizational Culture" in Public Administration Quarterly, Volume 17(1), pp.112-121.

Bass, B.M. \& B. Avolio. (2014). Improving Organizational Effectiveness through Transformational Leadership. Thousand Oaks, CA: Sage.

Batool, Bano Fakhra. (2013). "Emotional Intelligence and Effective Leadership" in JBSQ: Journal of Business Studies Quarterly, Vol.4, No.3. Available online also at: http://citeseerx.ist.psu. edu/viewdoc/download?doi=10.1.1.652.8649\&r ep $=$ rep1\&type $=p d f[$ accessed in Ilorin, Nigeria:
August 24, 2019].

Bausseron, Elise. (2018). “The Case for Strategic Emotional Intelligence: Extension and Test of a Model". Unpublished Ph.D. Thesis. Australia: University of Queensland Business School, the University of Queensland. Available online also at: https://espace.library.uq.edu.au/data/ UQ 724327/s4278608 final thesis.pdf [accessed in Ilorin, Nigeria: August 24, 2019].

Bergman, Jerry. (2018). "The Dark Side of Charles Darwin: A Critical Analysis of an Icon of Science". Available online at: http://sarkoups.free. fr/darwinbergman.pdf [accessed in Ilorin, Nigeria: August 24, 2019].

Boyatzis, Richard E. et al. (1999). "Clustering Competence in Emotional Intelligence: Insights from the Emotional Competencie Inventory (ECI)". Available online at: http://www. eiconsortium.org/pdf/eci acticle.pdf [accessed in Ilorin, Nigeria: August 10, 2019].

Brown, F. William \& Michael D. Reilly. (2008). "Emotional Intelligence, Transformational Leadership, and Gender: Correlation and Interaction Possibilities" in The Journal of International Management Studies, Vol.3, No.2 [August], pp.1-9.

Burns, J.M. (1978). Leadership. New York: Harper \& Row.

Burns, J.M. (2003). Transforming Leadership: A New Pursuit of Happiness. New York: Atlantic Monthly Press.

Bushiri, Christabella P. (2014). "The Impact of Working Environment on Employees' Performance: The Case of Institute of Finance Management in Dar Es Salaam Region". Unpublished Ph.D. Dissertation. Tanzania: The Open University of Tanzania. Available online also at: https://core.ac.uk/download/ pdf/33424874.pdf?repositoryId $=743$ [accessed in Ilorin, Nigeria: September 9, 2019].

Cannella, A.A. \& M.J. Monroe. (2017). "Contrasting Perspectives on Strategic Leaders: Towards a More Realistic View of Top Managers" in Journal of Management, Volume 23, pp.213-221.

Carson, K.D., P.P. Carson \& B.J. Birkenmeier. (2010). "Measuring Emotional Intelligence: Development and Validation of an Instrument" in Journal of Behavioral and Applied Management, Volume 2(1), pp.32-44.

Certo, S.C. (2012). Modern Management. New Delhi: Prentice Hall, $9^{\text {th }}$ edition.

Cherry, Kendra. (2018). "Overview of Emotional Intelligence: History and Measures of Emotional Intelligence". Available online at: https:// www.strategically.com.au/pdfs/Overview-ofEmotional-Intelligence.pdf [accessed in Ilorin, 
Nigeria: August 17, 2019].

Cole, G.A. (2012). Personnel and Human Resources Management. London: Book Power, $5^{\text {th }}$ edition.

Cooper, R. (2017). “Applying Emotional Intelligence in the Workplace" in Training and Development Journal, Volume 51(12), pp.31-38.

Darwin, C. (1872). The Expression of Emotions in Man and Animals. London: John Murray, DOI:10.1037/10001-000.

Dawkins, Harry A. (2011). "Transformational Leadership: A Contribution to the Effectiveness of Congregationally Formed Faith-Based Community Development Corporations" in Education Doctoral Paper, No.63. Available online also at: https://fisherpub.sjfc.edu/cgi/viewcontent.cg i? article $=1064 \&$ context $=$ education etd [accessed in Ilorin, Nigeria: September 9, 2019].

Desrosiers, Patricia. (2015). "Leadership Style in Social Work Educational Administration" in International Journal of Business and Social Science, Vol.6, No.3 [March]. Available online also at: http://ijbssnet.com/journals/Vol 6 No 3 March 2015/1.pdf [accessed in Ilorin, Nigeria: September 9, 2019].

Dev, Jeevan Jyoti Manisha. (2015). “The Impact of Transformational Leadership on Employee Creativity: The Role of Learning Orientation" in Journal of Asia Business Studies, Vol.9, Iss.1, pp.78-98. Available online also at: http://dx.doi. org/10.1108/JABS-03-2014-0022 [accessed in Ilorin, Nigeria: August 17, 2019].

Dias, M.A.M.J. \& R.S.G.E. Borges. (2017). "Performance and Leadership Style: When Do Leaders and Followers Disagree?" in Mackenzie Management Review, Volume 18(2), pp.104-129. Available online also at: https://www.scielo.br/ pdf/ram/v18n2/1678-6971-ram-18-02-0104.pdf [accessed in Ilorin, Nigeria: September 9, 2019].

Drucker, R.E. (2010). "Lessons for Successful NonProfit Governance" in Non-Profit Management \& Leadership, Volume 1(1), pp.7-14.

Evangelides, Pavlos \& Nikos Karfakis. (2019). "Leaderships Styles, Preferences, and Effectiveness: Empirical Evidence from the Cyprus Banking Sector" in ECONOMICA: Acta Universitatis Danubius, Vol.15, No.2. Available online also at: http://journals.univ-danubius.ro/ index.php/oeconomica/article/view/5291/5215 [accessed in Ilorin, Nigeria: January 10, 2020].

Faulk, Gregory K., Robert P. Lambert \& Clyde Philip Rolston. (2005). "The Effects of Changing Technology and Government Policy on the Commercialization of Music" in Journal of Nonprofit \& Public Sector Marketing, Volume 13:1-2, pp.75-90. DOI:10.1300/ J054v13n01_05.
Fiori, Marina \& Ashley K. Vesely-Maillefer. (2018). "Emotional Intelligence as an Ability: Theory, Challenges, and New Directions" in K.V. Keefer et al. [eds]. Emotional Intelligence in Education. New York: The Springer Series on Human Exceptionality, pp.23-47. Available online also at: https://doi.org/10.1007/978-3-319-90633-1_2 [accessed in Ilorin, Nigeria: August 10, 2019].

Foster, D.E. (2002). "A Method of Comparing Follower Satisfaction with the Authoritarian, Democratic, and Laissez-faire Styles of Leadership" in Communication Teacher, Volume 16(2), pp.4-6.

Fry, Heather, Steve Ketteridge \& Stephanie Marshall [eds]. (2009). A Handbook for Teaching and Learning in Higher Education: Enhancing Academic Practice. New York and London: Routledge, third edition.

Gellis, Z.D. (2011). "Social Work Perception of Transformational and Transactional Leadership in Health Care" in Social Work Research, Volume 25(1), pp.17-25.

Gentles, S.J. et al. (2016). "Reviewing the Research Methods Literature: Principles and Strategies Illustrated by a Systematic Overview of Sampling in Qualitative Research" in Systematic Review, Volume 5:172. Available online also at: https:// doi.org/10.1186/s13643-016-0343-0 [accessed in Ilorin, Nigeria: August 10, 2019].

Goleman, D. (1995). Emotional Intelligence. New York: Bantam Books.

Gomes, A. Rui. (2018). “Transformational Leadership: Theory, Research, and Application to Sports". Available online at: https://core.ac.uk/ download/pdf/55627312.pdf [accessed in Ilorin, Nigeria: August 3, 2019].

Grandey, Alicia A. (2000). "Emotion Regulation in the Workplace: A New Way to Conceptualize Emotional Labor" in Journal of Occupational Health Psychology, Vol.5, No.1, pp.95-110. Available online also at: http://php.scripts.psu. edu/users/a/a/aag6/GrandeyJOHP.pdf [accessed in Ilorin, Nigeria: August 17, 2019].

Hendrix, Dana. (2018). "Emotional Intelligence and the Winds of Change in Academic Libraries". Available online at: http://www.ala.org/acrl/ sites/ala.org.acrl/files/content/conferences/ confsandpreconfs/2013/papers/Hendrix Emotional.pdf [accessed in Ilorin, Nigeria: August 24, 2019].

Higgins, Elizabeth A. (2015). "The Influence of Nurse Manager Transformational Leadership on Nurse and Patient Outcomes: Mediating Effects of Supportive Practice Environments, Organizational Citizenship Behaviours, Patient Safety Culture and Nurse Job Satisfaction" in Electronic Thesis 
and Dissertation Repository, No.3184. Available online also at: https://ir.lib.uwo.ca/etd/3184 [accessed in Ilorin, Nigeria: August 24, 2019].

Hughes, Tawney A. (2014). "Idealized, Inspirational, and Intellectual Leaders in the Social Sector: Transformational Leadership and the Kravis Prize" in CMC Senior Theses Paper, No.906. Available online also at: http://scholarship. claremont.edu/cmc theses/906 [accessed in Ilorin, Nigeria: August 31, 2019].

Ipuele, O.A. \& A.F. Aondoaseer. (2013). "Leadership Styles as Recipes for Transformation" in International Journal of Business and Management Review, Vol.1, No.4 [December], pp.35-53. Available online also at: http://www. eajournals.org/wp-content/uploads/LeadershipStyles-as-Recipes-for-Transformation.pdf [accessed in Ilorin, Nigeria: September 9, 2019].

Jandaghi, G., H.Z. Martin \& A. Farjami. (2019). "Comparing Transformational Leadership in Successful and Unsuccessful Companies". Unpublished Ph.D. Thesis. Aberdeen: University of Aberdeen.

Jenner, Melissa V. (2019). “Transformational and Transactional Leadership Behaviors Influence Employee Job Satisfaction within a Federal Government Organization". Unpublished Doctoral Dissertation. USA [United States of America]: Donald Tapia School of Business, Faculty of Saint Leo University. Available online also at: https://search.proquest.com/openview/ c2b16b20a30da19dd9675553d54600cd [accessed in Ilorin, Nigeria: January 24, 2020].

Karavelioglu, A.M. (2014). "Analysis of Leadership Styles in Banking Sector in North-Cyprus: Testing Factors Effecting Authoritarian Style and a Mode for Banking Sector in a Small Island". Unpublished Academic Paper. Available and owned by Author.

Karim, Jahanvash. (2011). "Emotional Intelligence: A Cross-Cultural Psychometric Analysis". Unpublished Ph.D. Thesis. d'Aix-Marseille: Universite de Paul Cezanne.

Kerr, Robert et al. (2006). "Emotional Intelligence and Leadership Effectiveness" in Leadership \& Organization Development Journal, Vol.27, No.4, pp.265-279. Available online also at: https://manajemenrumahsakit.net/wp-content/ uploads/2012/09/EI-leadership-effectiveness.pdf [accessed in Ilorin, Nigeria: August 24, 2019].

Keskes, I. (2014). "Relationship between Leadership Styles and Dimensions of Employee Organizational Commitment: A Critical Review and Discussion of Future Directions" in Intangible Capital, Volume 10(1), pp.2651. Available online also at: http://dx.doi. org/10.3926/ic.476 [accessed in Ilorin, Nigeria: September 9, 2019].

Kolzow, David R. (2014). "Leading from Within: Building Organizational Leadership Capacity". Available online at: https://www.iedconline.org/ clientuploads/Downloads/edrp/Leading_from Within.pdf [accessed in Ilorin, Nigeria: August 10, 2019].

Kotter, J.P. (2011). "What Leaders Really Do" in On Leadership: HBR'S 10 Most Reads. Boston, Massachusetts: Harvard Business Review Press.

Kouzes, J.M. \& B.Z. Posner. (2012). The Leadership Challenges. San Francisco: Jossey Bass, $3^{\text {rd }}$ edition.

Kővári, Edit Mária. (2016). "Don’t Worry, be Emotionally Intelligent: Hotel Functional Managers' Trait Emotional Intelligence and its Relation to Task and Contextual Performance within Organisational Culture in Hungary". Unpublished Ph.D. Thesis. UK [United Kingdom]: University Of Derby. Available online also at: https://derby.openrepository.com/ bitstream/handle/10545/614995/Edit_Kovari PhD 2016\%20 UDORA.pdf [accessed in Ilorin, Nigeria: August 10, 2019].

Kraines, G. (2011). Accountability Leadership: How to Strengthen Productivity through Sound Managerial Leadership. USA [United States of America]: Career Press, Inc.

Langley, A. (2010). "Emotional Intelligence: A New Evaluation for Management Development?" in Career Development International, Volume 5(3), pp.177-183.

Lea, Sean. (2019). "The Four Elements of Transformational Leadership". Available online at: https://www.businessballs.com/leadershipstyles/four-is-of-transformational-leadership/ [accessed in Ilorin, Nigeria: January 9, 2020].

Lee, M. (2014). "Transformational Leadership: Is it Time for a Recall?” in International Journal of Management and Applied Research, Vol.1, No.1, pp.17-29. Available online also at: https://doi. org/10.18646/2056.11.14-002 [accessed in Ilorin, Nigeria: August 31, 2019].

Leithwood, Kenneth et al. (2004). "Executive Summary: How Leadership Influences Student Learning". Available online at: https://www. wallacefoundation.org/knowledge-center/ Documents/How-Leadership-Influences-StudentLearning.pdf [accessed in Ilorin, Nigeria: August 31, 2019].

Li, Hui et al. (2019). "Influence of Transformational Leadership on Employees' Innovative Work Behavior in Sustainable Organizations: Test of Mediation and Moderation Processes" in SUSTAINABILITY, Volume 11:1594. doi:10.3390/ su11061594. 
Lowe, K.B., K.G. Kroeck \& N. Sivasubramaniam. (2016). "Effectiveness Correlates of Transformational and Transactional Leadership: A Meta-Analytic Review of the MLQ Literature" in Leadership Quarterly, Volume 7(3), pp.385-426.

Lubke, Jennifer K. (2013). "Understanding Contradictions in Teacher-Learner Identity, Digital Video, and Goal-Directed Activity in a Blended Graduate Reading Education Course". Unpublished Ph.D. Dissertation. Knoxville: University of Tennessee. Available online also at: https://trace.tennessee.edu/utk_graddiss/2596 [accessed in Ilorin, Nigeria: August 31, 2019].

Ludwig, R.J. \& M.G. Welch. (2019). “Darwin's Other Dilemmas and the Theoretical Roots of Emotional Connection" in Frontiers in Psychology, Volume 10:683 [April]. Available online also at: https://www.ncbi.nlm.nih.gov/ pmc/articles/PMC6473325/ [accessed in Ilorin, Nigeria: January 24, 2020].

Malakyan, Petros G. (2015). “Depersonalizing Leadership and Followership: The Process of Leadship and Followship" in World Journal of Social Science Research, Vol.2, No.2. Available online also at: www.scholink.org/ojs/index.php/ wjssr [accessed in Ilorin, Nigeria: August 31, 2019].

Mandell, B. \& S. Pherwani. (2013). "Relationship between Emotional Intelligence and TL Style: A Gender Comparison" in Journal of Business \&Psychology, Volume 17(3), pp.387-404.

Manktelow, J. \& A. Carlson. (2014). “Developing Strong 'People Skills"'. Available online at: http://www.mindtools.com/pages/article/ newCDV 59.htm [accessed in Ilorin, Nigeria: August 17, 2019].

Mansaray, Hassan Elsan. (2019). "The Role of Leadership Style in Organisational Change Management: A Literature Review" in Journal of Human Resource Management, Vol.7, No.1, pp.18-31. doi:10.11648/j.jhrm.20190701.13.

Mayer, J.D. \& P. Salovey. (1997). "What is Emotional Intelligence?” in P. Salovey \& D.J. Sluyter [eds]. Emotional Development and Emotional Intelligence: Educational Implications. New York: Basic Books, pp.3-34.

Milius, Jeanette. (2019). “A Phenomenological Study of Leadership Outcomes in Short-Term Study Abroad" in Theses, Dissertations \& Student Scholarship: Agricultural Leadership, Education \& Communication Department, No.111. Available online also at: https://digitalcommons.unl.edu/ aglecdiss/111 [accessed in Ilorin, Nigeria: January 30, 2020].

Mulcahy, Dianne. (1999). "Training for New Times: Changing Relations of Competence, Learning, and Innovation" in Studies in
Continuing Education, Volume 21:2, pp.217238, DOI:10.1080/0158037990210205.

Mullin, Ann G. \& John L. Keedy. (1998). “Examining a Superintendent's Transformational Leadership: From the Model to Successful Practice". Paper presented at the Annual Meeting of the American Educational Research Association, in San Diego, CA, on April 13-17. Available online also at: https://files.eric.ed.gov/ fulltext/ED421758.pdf [accessed in Ilorin, Nigeria: August 24, 2019].

Norris, Christine F. (2014). "Perception and Communication of Non-Verbal Emotion: In Close Relationships" in Student Research Paper, No.20. Available online also at: https://scholarship. depauw.edu/cgi/viewcontent.cgi? article $=1016 \&$ co $\underline{\mathrm{ntext}}=$ studentresearch [accessed in Ilorin, Nigeria: August 17, 2019].

Nwokocha, Izidor. (2016). "Managing Reward Strategy to Enhance Employee Performance, Retention, and Productivity in Organizations: A General Overview" in INJODEMAR: International Journal of Development and Management Review, Volume 11 [June], pp.20-38.

O’Brien, Elaine \& Carol Linehan. (2014). “A Balancing Act: Emotional Challenges in the HR Role" in Journal of Management Studies, Volume 51(8), December. doi:10.1111/joms.12098.

Odumeru, J.A. \& I.G. Ogbonna. (2013). "Transformational vs. Transactional Leadership Theories: Evidence in Literature" in IRMBR: International Review of Management and Business Research, Vol.2, Iss.2. Available online also at: https://www.irmbrjournal.com/ papers/1371451049.pdf [accessed in Ilorin, Nigeria: August 17, 2019].

Omeluzor, Saturday U. (2018). “Organizational Culture Variables as Factors Influencing Librarians' Turnover Intentions in University Libraries in South-South and South-East of Nigeria" in Library Philosophy and Practice: e-Journal, Volume 1693. Available online also at: https://digitalcommons.unl.edu/libphilprac/1693 [accessed in Ilorin, Nigeria: August 24, 2019].

Osuigwe, Nkem Ekene et al. (2013). "Emotional Intelligence of Library Leaders and Innovative Library Services in South East Nigeria" in Information and Knowledge Management, Vol.3, No.10, pp.42-52.

Pasha, Syed Mansoor. (2016). "Inspiring Leadership through Emotional Intelligence" in IRJET: International Research Journal of Engineering and Technology, Vol.03, Iss.06 [June]. Available online also at: https://irjet.net/archives/V3/i6/ IRJET-V3I6318.pdf [accessed in Ilorin, Nigeria: August 17, 2019]. 
Petrick, J. et al. (2019). “Global Leadership Skills and Reputational Capital: Intangible Resources for Sustainable Competitive Advantage" in Academy Management Executive, Volume 2, pp.58-69.

Ramesh, R.S. \& M. Hegde. (2017). “The Impact of Transformational and Transactional Leadership on Organizational Performance: References in Literature" in PARIPEX: Indian Journal of Research, Vol.6, Iss.3 [March]. Available online also at: https://www.worldwidejournals. com/paripex/recent issues_pdf/2017/March/ March 2017 1491816606 142.pdf [accessed in Ilorin, Nigeria: September 9, 2019].

Read III, John Basil. (2018). "A Case Study of the Followership Role of Executive Assistants in Global Organizations". Unpublished Ph.D. Thesis. USA [United States of America]: College of Professional Studies, Indiana Institute of Technology. Available online also at: https:// search.proquest.com/openview/1e5403db2c3264 dff0e8dae11533cbd4 [accessed in Ilorin, Nigeria: August 24, 2019].

Reilly, Anthony J. (1998). "Three Approaches to Organizational Learning" in The Pfeiffer Library, Volume $16,2^{\text {nd }}$ edition. Available online also at: https://home.snu.edu/ jsmith/library/body/v16. pdf [accessed in Ilorin, Nigeria: August 10, 2019].

Riggio, R.E., I. Chaleff \& J. Lipman-Blumen [eds]. (2008). The Art of Followership: How Great Followers Create Great Leaders and Organizations. San Francisco, CA: Jossey-Bass, J-B Warren Bennis Series.

Roberts, Roshan Levina. (2005). "The Relationship between Rewards, Recognition, and Motivation at an Insurance Company in the Western Cape". Unpublished Master's Thesis. Cape Town, South Africa: Department of Industrial Psychology, University of the Western Cape. Available online also at: https://core.ac.uk/download/ pdf/58912541.pdf [accessed in Ilorin, Nigeria: September 9, 2019].

Salovey, P. \& J.D. Mayer. (1990). "Emotional Intelligence" in Imagination, Cognition, and Personality, Volume 9(3), pp.185-211.

Sani, Mad Khir Johari Abdullah et al. (2013). "Assessing the Emotional Intelligence Profile of Public Librarians in Malaysia: Descriptive Analysis" in Library Philosophy and Practice: e-Journal, Volume 1047. Available online also at: https://digitalcommons.unl.edu/libphilprac/1047 [accessed in Ilorin, Nigeria: August 17, 2019].

Sauter, Disa A. (2017). "The Nonverbal Communication of Positive Emotions: An Emotion Family Approach" in EMOTION REVIEW: Journal of the International Society for
Research on Emotion, Volume 9(3), pp.222-234. Available online also at: https:/www.ncbi.nlm. nih.gov/pmc/articles/PMC5542129/ [accessed in Ilorin, Nigeria: August 17, 2019].

Serrat, O. (2017). "Understanding and Developing Emotional Intelligence" in Knowledge Solutions. Published by Springer in Singapore. Available online also at: https://doi.org/10.1007/978-98110-0983-9 37 [accessed in Ilorin, Nigeria: August 24, 2019].

Shrestha, Nina. (2008). "A Study on Student's Use of Library Resources and Self-Efficacy". Unpublished M.A. Thesis. Kirtipur, Katmandu, Nepal: Central Department of Library and Information Science, Faculties of Humanities and Social Sciences, Tribhuvan University. Available online also at: http://eprints.rclis.org/22623/1/NinaShrestha.pdf [accessed in Ilorin, Nigeria: August 31, 2019].

Singh, Prakash. (2014). "Intervention of Transformational Collegial Leadership to Develop Human Resources" in International Business \& Economics Research Journal, Vol.13, No.1 [January/February], pp.53-68.

Singhal, Tarun Kumar, Bhawna Garg \& Deepak Saxena. (2014). "Organizational Productivity through Emotional Intelligence" in PRANJANA, Vol.17, No.1 [January-June], pp.47-55.

Snyder, Hannah. (2019). "Literature Review as a Research Methodology: An Overview and Guidelines" in Journal of Business Research, Volume 104 [November], pp.333-339. Available online also at: https://www.sciencedirect.com/ science/article/pii/S0148296319304564 [accessed in Ilorin, Nigeria: January 17, 2020].

Srivastava, Kalpana. (2013). "Emotional Intelligence and Organizational Effectiveness" in Industrial Psychiatry Journal, Volume 22(2), July-December, pp.97-99. Available online also at: https://www. ncbi.nlm.nih.gov/pmc/articles/PMC4085815/ [accessed in Ilorin, Nigeria: August 24, 2019].

Stephen, Makoji Robert. (2016). "Investigating the Role of Human Resource Development (HRD) Policy Formulation, Implementation, and Regulation of Academic Staff in Two Case Study Nigerian Polytechnic institutions". Unpublished Ph.D. Thesis. Salford, UK [United Kingdom]: College of Business and Law, University of Salford. Available online also at: https://core. ac.uk/download/pdf/46569474.pdf [accessed in Ilorin, Nigeria: August 10, 2019].

Taylor, Aisha Smith. (2015). "Transformational Leadership, Diversity, and Creativity at Work: A Moderated Mediation Model" in Dissertations and Theses Paper, No.2341. Available online also at: https://doi.org/10.15760/etd.2338 [accessed in Ilorin, Nigeria: August 31, 2019]. 
Thomson, Thomas M. (1998). "Management by Objectives" in The Pfeiffer Library, Volume 20, $2^{\text {nd }}$ Edition. Available online also at: https://home. snu.edu/ jsmith/library/body/v20.pdf [accessed in Ilorin, Nigeria: September 9, 2019].

Truninger, M. et al. (2018). "The Power of EI Competencies Over Intelligence and Individual Performance: A Task-Dependent Model" in Frontiers of Psychology, Volume 9:1532 [September]. Available online also at: https://www.ncbi.nlm.nih.gov/pmc/articles/ PMC6137254/ [accessed in Ilorin, Nigeria: August 10, 2019].

Ugoani, John N.N. (2015). "Emotional Intelligence and Personality Stability Among Urban Adolescents in Nigeria" in Advances in Applied Psychology, Vol.1, No.2, pp.135-144. Available online also at: https://pdfs.semanticscholar.org/9 5b7/893f1b92dc3f3c7c6b42932b88700c5019e5. pdf [accessed in Ilorin, Nigeria: August 24, 2019].

Walters, Stephan Lorentz. (2018). "Emotional Intelligence and Leader Development:

Measuring Trait Emotional Intelligence Scores of MidCareer Commissioned U.S. Army Officers" in Dissertations Paper, No.148. Available online also at: https://digitalcommons.wku.edu/diss/148 [accessed in Ilorin, Nigeria: August 31, 2019].

Wijesundera, L.K. (2018). "A Study on the Impact of Motivation on Employee Performance: An
Exploratory Case Study on a Dubai Based SemiGovernment Commercial Bank". Unpublished M.B.A. Thesis. UK [United Kongdom]: Cardiff School of Management, Cardiff Metropolitan University. Available online also at: https://repository.cardiffmet.ac.uk/bitstream/ handle/10369/9664 [accessed in Ilorin, Nigeria: September 9, 2019].

Woods, A.P. (2010). "Democratic Leadership: Drawing Distinctions with Distributed Leadership" in International Journal of Leadership in Education, Volume 7(1), pp.336. doi:10.1080/1360312032000154522.

Xenikou, Athena. (2017). "Transformational Leadership, Transactional Contingent Reward, and Organizational Identification: The Mediating Effect of Perceived Innovation and Goal Culture Orientations" in Frontiers in Psychology, Volume 8:1754 [October]. Available online also at: https://www.ncbi.nlm.nih.gov/pmc/articles/ PMC5651821/ [accessed in Ilorin, Nigeria: September 9, 2019].

Yukl, Gary \& Rubina Mahsud. (2010). "Why Flexible and Adaptive Leadership is Essential" in Consulting Psychology Journal: Practice and Research, Vol.62, No.2, pp.81-93. Available online also at: https://pdfs.semanticscholar.org/1f ae/5d54bc194adce1d785c90a234f57034380f9.pdf [accessed in Ilorin, Nigeria: August 31, 2019]. 


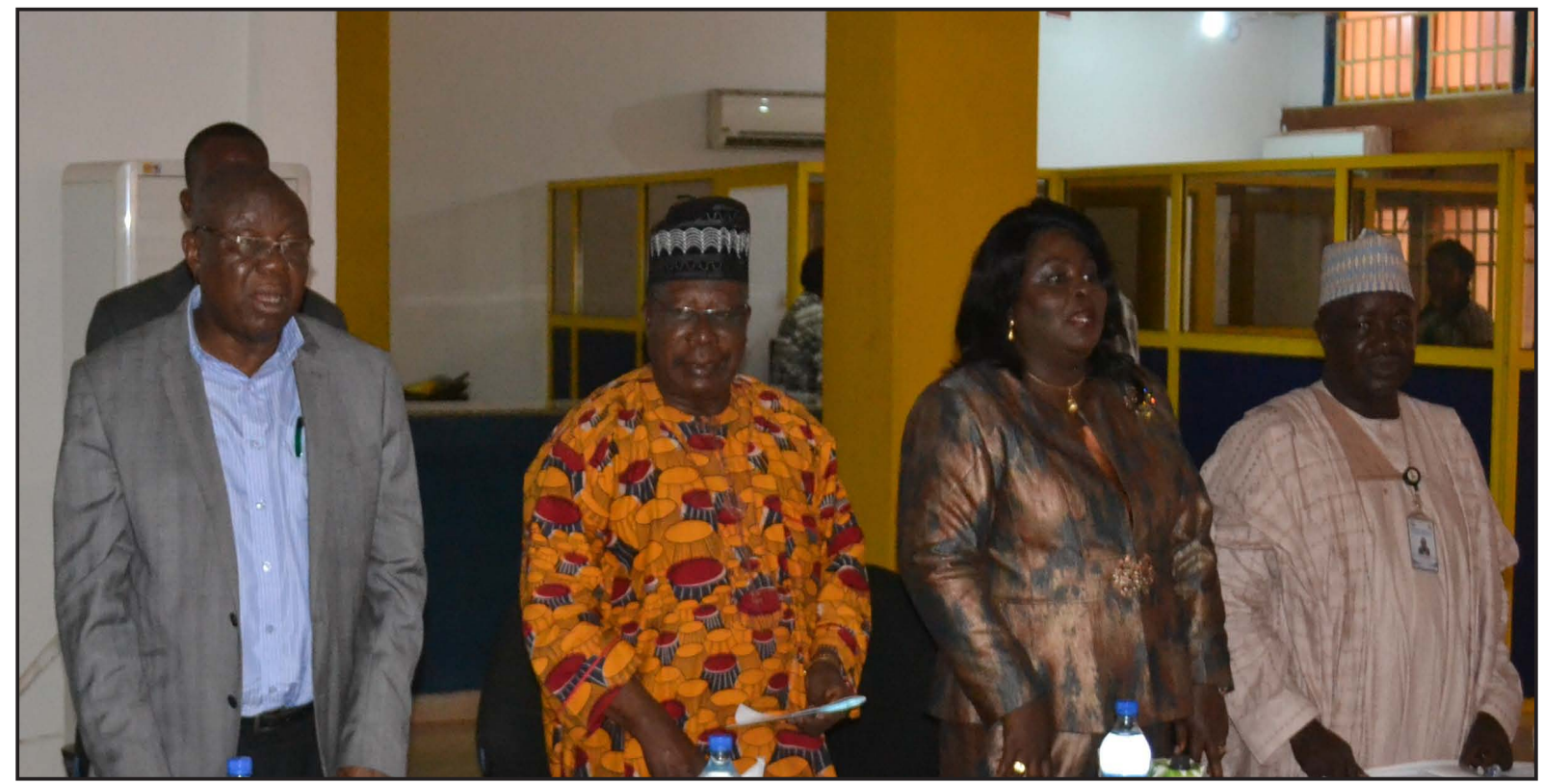

\section{Nigerian Librarians}

(Source: https://www.sunnewsonline.com/lrcn, 30/1/2020)

There is dearth of research in the area of assessing and enhancing emotional intelligence among Nigerian librarians. Attempts made to uncover related studies in this area have proved abortive. It is anticipated that the position of this paper will provide baseline information for research as to how emotional intelligence affects leadership styles in the library organisation. By using the qualitative approaches and literature review, this study tries to elaborate key concepts of leadership and its relationsship with the Nigerian librarians, such as: Concept of Emotional Intelligence; Emotional Intelligence and Leadership; Leadership and Leadership Style; the TransformationalTransactional Leadership Style Theory by J.M. Burns was Used to Explain the Concept of Leadership Style; and Relevance of J.M. Burns Theory to this Study. 